\title{
WestVirginiaUniversity.
}

Department of Economics

Working Paper Series

\section{Abnormal Returns from Joining Congress? Evidence from New Members}

Joshua C. Hall

Serkan Karadas

Minh Tam T. Schlosky

Working Paper No. 16-25

This paper can be found at the College of Business and Economics Working Paper Series homepage: 


\title{
Abnormal Returns from Joining Congress? Evidence from New Members*
}

\author{
Joshua C. Hall ${ }^{\dagger}$ \\ Serkan Karadas $\ddagger$ \\ Minh Tam T. Schlosky ${ }^{\S}$
}

November 26, 2016

\begin{abstract}
Past research shows that members of Congress are informed traders, i.e., that they earn abnormal returns while in office. This important research does not identify whether being elected leads to informed trading or whether informed traders are selected into office. We try to provide a partial answer to this question by looking at whether new members of Congress were informed traders prior to being elected and how their portfolio performance changes after election and appointment to different types of committees. Due to data limitations our analysis focus on the pre-congressional (i.e., election) and congressional (i.e., post-election) common stock trades made by newly elected members of Congress from 2004-2010. We find weak evidence of informed trading for the pre-Congress period, suggesting that informed traders are not being selected into office. When combined with our finding that the portfolios of members serving on powerful committees outperform the market during their second term in office, this provides additional evidence that serving on influential committees is the mechanism by which members of Congress earn abnormal returns.
\end{abstract}

Keywords: informed trading, congressional trading, the STOCK Act

*We thank Jason P. Berkowitz and the participants at the University of the South's Economics Department seminar, Eastern Finance Association (EFA) meetings, and Dwight Lee, Russell Sobel, and session participants at the 86th annual meeting of Southern Economic Association (SEA) for their helpful comments. We are also thankful to Courtney Saunders for her research assistance. All remaining errors belong to us.

${ }^{\dagger}$ Joshua C. Hall, Department of Economics, West Virginia University, Morgantown WV 26506. E-mail: joshua.hall@mail.wvu.edu

${ }^{\ddagger}$ Serkan Karadas, Department of Economics, Sewanee: The University of the South, Sewanee, TN 37383. E-mail: skaradas@sewanee.edu.

${ }^{\S}$ Minh Tam Tammy Schlosky, Department of Economics, Sewanee: The University of the South, Sewanee, TN 37383. E-mail: schlosky@sewanee.edu. 


\section{Introduction}

Two influential studies by Ziobrowski et al. (2004, 2011) analyzed the stock transactions that members of Congress (members) made prior to 2002, and uncovered that their portfolios earn abnormal returns. Members of Congress were not liable for insider trading on material nonpublic information during this period (Bainbridge, 2011). In response to public criticism, Congress passed the Stop Trading on Congressional Knowledge (STOCK) Act in 2012, which explicitly banned trading on legislative information and required mandatory online disclosure of congressional trades. Within a year, however, mandatory online disclosures were eliminated, putatively due to national security concerns (Vardi, 2013).

The passage and the partial repeal of the STOCK Act led to further interest in Congressional stock trades. Eggers and Hainmueller (2014) found that politicians' investments in local stocks generate modest abnormal returns. Karadas (2015) investigated the information content of congressional stock transactions from 2004-2010 period and documented that members of Congress trade on time-sensitive information. In addition, he found that most of the value-relevant information is possessed by members of Congress serving on powerful committees. This growing literature suggests that members of Congress are informed traders because of the information component and power related to their Congressional service. It could be, however, that the political process is more likely to result in informed traders becoming members of Congress.

We provide evidence that membership in Congress leads to abnormal returns by looking at the available evidence on trading by new members of Congress before they are elected and how their trading evolves over their first few terms in office. In compliance with the House and Senate ethics rules, members of Congress report their financial transactions during

election and congressional service years. We obtain members' common stock transactions from the Center for Responsive Politics (CRP) for the 2004-2010 period. We choose this time period because the CRP data begin in 2004 and 2010 is the last year prior to active discussion of regulating Congressional trading activity. In that way, our results are not 
tainted by any anticipated responses to the proposals that ultimately became the STOCK Act.

Employing CRP data, we first identify all first-time members of Congress who traded common stocks during the election period and measure the information content of their transactions via transactions-based calendar-time portfolios. In the second part of our analysis, we identify new members of Congress who consistently traded stocks during their election year and two subsequent congressional terms and measure their portfolio performance. Our analysis shows that there is weak and inconsistent evidence of informed trading by members of Congress prior to their Congressional service. Furthermore, it takes two consecutive terms for members to be able to make informed trades, but this advantage is restricted only to those who serve on powerful committees as defined by the well known Grosewart method (Groseclose and Stewart III, 1998; Stewart III, 2012). Our results imply that there are returns to joining Congress, but these returns are not equally distributed across members. More importantly, we show that members of Congress are not informed traders in the period leading up to their elections. This is further evidence that the source of abnormal returns is either information or power related to their Congressional service.

In addition, our paper contributes to public choice theory in two ways. First, there is a large literature on the supply and demand for committee assignments (Shepsle, 1975; Munger, 1988; Grier and Munger, 1991; Coker and Crain, 1994; Groseclose and Stewart III, 1998). By providing evidence that members of powerful committees earn abnormal returns, we provide additional insight into the demand for certain committee assignments beyond the ability to receive higher campaign contributions (Grier and Munger, 1991; Groseclose and Stewart III, 1998). Second, Henry Manne observed over 50 years ago that the largest producer of information that could influence the stock market is the federal government (Manne, 1966). Our results highlight the possibility that members of Congress either trade on material nonpublic information or use committee assignments to influence policy in a way that targets specific firms or sectors (Fisman, 2001; Knight, 2006) in a manner that 
enriches themselves (Milyo, 2014). With the exception of Anderson et al. (1994), we know of no public choice papers highlighting abnormal returns of politicians.

We proceed as follows. Section 2 summarizes our data on trading by members of Congress, while Section 3 describes our empirical approach. In Section 4, we present our empirical results, and Section 5 concludes the paper.

\section{Data}

We obtain congressional common stock transactions data from the Center for Responsive Politics (CPR) for the 2004-2010 period. ${ }^{1}$ We exploit the fact that members of Congress not only report their common stock transactions during their congressional service years but also during the years that they first run for Congress. We obtain the list of freshmen members of Congress in every congressional term from publicly-available sources. Then we determine the trades that these new members made before and after they joined the Congress.

Table 1 provides an overview of the sample selection procedure. For the 2004-2010 sample period, we have trades from the members who served or ran for the $108^{\text {th }}$ to the $112^{\text {th }}$ Congress. We drop trades by members who transitioned from the House to the Senate as they are not new in Congress. We also exclude members of Congress who served in Congress previously and were running for re-election. After applying these filters, we have 71 newly elected members of Congress in our sample, who placed a total of 3,416 stock transactions during their election years. These members ran for the $109^{\text {th }}$ Congress in 2004, the $110^{\text {th }}$ Congress in 2006, the $111^{\text {th }}$ Congress in 2008, and finally the $112^{\text {th }}$ Congress in 2010.

Forty of the 71 new members do not have congressional (post-election) stock transactions.

\footnotetext{
${ }^{1}$ There have been substantial delays in the reporting of congressional stock transactions. These trades were reported via paper-based filings by members 5 to 17 months after they took place. The Center for Responsive Politics has done a valuable service in converting these paper-based records to usable data sets. Nevertheless, this entire process causes 2 to 3 years delays in making the data available to the public. Furthermore, congressional transactions data are very challenging to clean. See Karadas (2015) for the details of the data cleaning process.
} 
Recall that our data covers stock transactions only until the end of 2010. As a result, some of these 40 members may have traded stocks at some point in their congressional career, but their trades will not show up in our sample if they were placed after 2010. For example, this is most likely the case for those who ran for the $112^{\text {th }}$ Congress in 2010.

That leaves us with 31 members of Congress who placed trades before and after they started serving in Congress. These members placed 1,744 pre-congressional and 13,210 congressional stock transactions. Some of these members did not trade every year. For example, only 22 of these 31 members traded in the first term that they served in Congress. A further look at the sample reveals that there are only 16 new members of Congress who traded stocks both in the election year and two consecutive terms following their election.

\section{Empirical Methodology}

\subsection{Empirical Setup}

Following Ziobrowski et al. (2004), we first construct synthetic portfolios to examine the portfolio performance of new members of Congress. We set up a portfolio of buy transactions (buy portfolio) and a portfolio of sell transactions (sell portfolio) for each member in our sample using daily stock returns from the Center for Research in Security Prices (CRSP). A buy portfolio tracks the performance of the stocks that a member purchases, from the purchase date to a specified future date. Similarly, a sell portfolio tracks the performance of the stocks that a member sells from his or her portfolio. If a member buys before stock

prices rise, his or her buy portfolio will perform well. On the other hand, if he or she sells before stock prices drop, the sell portfolio will perform poorly, which is translated into losses avoided by selling at the right time. Both of these cases imply the presence of informed trading.

In constructing member-level buy and sell portfolios, we weight individual transactions either equally or by transaction dollar amount. We allow a transaction to stay in the portfo- 
lio under six different holding periods, which are 1/4, 1, 2, 3, 6, and 12 months. Accordingly, under the 1/4-month (one-week) holding period, transactions are put into the portfolio on the day they occur, and they are discarded from the portfolio one week later. These holding periods reveal information about the time-sensitivity of transactions. For example, if portfolios perform very well under a 1/4-month holding period, but perform poorly under a 12-month holding period, we can then argue that new members of Congress trade on timesensitive information as the information content of trades disappears for the longer holding periods. After constructing member-level portfolios, we compute average portfolio returns by equally weighting member-level portfolios for every trading day. This way we prevent extremely successful or unsuccessful traders from skewing the results. In the final step, we compound daily returns to generate monthly returns, and then create a buy-minus-sell portfolio as the difference between monthly buy portfolio returns and sell portfolio returns. We primarily focus on the buy-minus-sell portfolio as it simultaneously tracks the performance of buy and sell transactions.

\subsection{Risk-Adjusted Performance Measure}

We are interested in measuring the performance of the buy-minus-sell portfolios constructed from the new members' transactions. If members are informed traders, we anticipate the sign of the returns on these portfolios to be positive (Odean, 1999). However, such a sign analysis does not suffice to produce a risk-adjusted performance measure. For this purpose, we resort to the conventional performance evaluation models in finance. In particular, we use Capital Asset Pricing Model, Fama-French 3-Factor Model (Fama and French, 1993), Carhart 4Factor Model (Carhart, 1997), and liquidity-added 5-Factor Model (Pástor and Stambaugh, 2003). We obtain the data for these models from Wharton Research Data Services (WRDS).

Below we specify the Capital Asset Pricing Model (CAPM) as our baseline model:

$$
r_{p, t}=\alpha+\beta_{p}\left(r_{m, t}-r_{f, t}\right)+\varepsilon_{p, t}
$$


where $r_{p, t}$ is the return on the new members' buy-minus-sell portfolio in month $t$. The dependent variable is the excess market returns rewarded over the risk-free rate. Our main interest in this model is the intercept, $\alpha$ (alpha), which captures the magnitude of abnormal performance (i.e., abnormal returns). The rest of the models add additional variables to the CAPM, but we are still interested in the economic and statistical significance of the alpha. To distinguish between the alphas generated from each model, we separately label them as CAPMAlpha, FFAlpha, CarhartAlpha, and 5-Factor Alpha in our tables. The justification for estimating these four different models is that later ones are built on the earlier ones, controlling for additional factors. For example, the CAPM only controls for the market factor under the assumption that market returns alone determine the returns on a given stock. Fama-French 3-Factor Model controls for the factors that are related to the size (market capitalization) and value (book-to-market ratio) in addition to controlling for the market factor. Carhart 4-Factor Model adds a momentum factor to Fama-French 3-Factor Model to account for the short-time price trends in stock returns. 5-Factor Model is the most comprehensive model in our analysis, employing all the variables in Carhart model and an additional factor that captures the effect of illiquidity in stock returns.

A statistically significant positive alpha implies that politicians' portfolios have aboveaverage performance (abnormal returns) and that politicians are informed traders. On the other hand, a statistically significant negative alpha implies that politicians' portfolios have below-average performance and that politicians lack value-relevant information. A statistically insignificant alpha suggests that politicians have average portfolio performance with no informational advantage or disadvantage. For example, Odean (1999) examines the portfolio performance of retail traders by constructing buy-minus-sell portfolios and show that these portfolios underperform the market with negative alphas. If politicians are similar to retail traders, the results from our analysis should be similar to those reported by Odean (1999). 


\section{Empirical Analysis and Results}

\subsection{Are Members of Congress Informed Traders to Begin With?}

In order to determine whether members of Congress trade on value-relevant information prior to serving in Congress, we form a buy-minus-sell portfolio tracking the performance of the common stock transactions that new members made in the years they were running for elections. These election years are 2004 for the $109^{\text {th }}$ Congress, 2006 for the $110^{\text {th }}$ Congress, 2008 for the $111^{\text {th }}$ Congress, and 2010 for the $112^{\text {th }}$ Congress. Since we hold the transactions in the buy-minus-sell portfolio up to a year, the sample period for pre-congressional portfolio ranges from 2004M01 to 2011M12. In total, we use 3,416 pre-congressional common stock transactions made by 71 newly elected members of Congress.

The results in Table 2 provide partial support for the hypothesis that the pre-congressional transactions by new members of Congress do not have any value-relevant information such that a portfolio tracking their transactions will not earn abnormal returns. Panel A reveals that the portfolios constructed with equally weighted transactions have statistically positive abnormal returns in all of the specifications at the 12-month holding period, but the average portfolio returns are not statistically significant. Panel B demonstrates that there is even weaker evidence of informed trading for the portfolios with value-weighted transactions. Overall, these results suggest that while there is some evidence of informed trading in the member's pre-congressional transactions, the results lack strong statistical support and consistency.

\subsection{Portfolio Performance Through Time}

In the second part of the empirical analysis, we investigate how the portfolios of new members of Congress performs through time. In particular, we are interested in comparing portfolio performance on a congressional term (every two year) basis. In our data, there are 31 new members of Congress who reported a trade during and after their election year. However, 
some of these members have inconsistent trades. For example, there are 22 freshmen who reported trades in their first term in Congress, and 16 freshmen who reported trades in their second term in Congress. In order to create consistent portfolios across time, we exclusively focus on the new members of Congress who reported trades during their election year, in their first term, and in their second term in Congress. There are 16 members of Congress who qualify for this restriction with 1,409 pre-congressional and 8,468 congressional transactions. We call these members consistent traders. According to Table 1, the consistent traders were elected to the $109^{\text {th }}$ and the $110^{\text {th }}$ Congress since only then they could have trading data for two consecutive terms based on our sample period.

We first create a pre-congressional portfolio to measure the extent of informed trading by the consistent traders prior to their congressional service. Next, we create two post-election portfolios based on our sample period:

1. First Congress Portfolio: This portfolio tracks the performance of the common stock transactions that the consistent traders made in the first term that they served in Congress. The first term covers years 2005 and 2006 for those elected to the $109^{\text {th }}$ Congress and 2007 and 2008 for those elected to the $110^{\text {th }}$ Congress. There are a total of 2,996 transactions by the consistent traders that took place in their first term. Since we hold a given buy-minus-sell portfolio up to 12 months, the sample period for the first congress portfolio ranges from 2005M01 to 2009M12.

2. Second Congress Portfolio: This portfolio tracks the performance of common stock transactions that the consistent traders made in the second term that they served in Congress. The second term covers years 2007 and 2008 for those elected to the $109^{\text {th }}$ Congress, and it includes years 2009 and 2010 for those elected to the $110^{\text {th }}$ Congress. There are a total of 5,472 transactions by the consistent traders that took place in their second term. The sample period for the second congress portfolio ranges from 2007M01 to 2011M12. 
We present the empirical results in Tables 3,4 and 5. There is not any evidence of informed trading in the transactions that the consistent traders placed during their election period. Table 4 indicates that the lack of positive abnormal returns persist in the first term. However, the abnormal returns in Table 5 suggest that members of Congress start trading on value-relevant information by the time they are in their second term in Congress resulting in economically significant abnormal returns. For example, the 5-Factor Alpha under a 12month holding period implies an annual abnormal performance of 9.82\% (0.818x12) in Panel A and $8.93 \%(0.744 x 12)$ in Panel B. Nevertheless, the evidence of informed trading in the second term is not robust to alternative model specifications. Overall, these results imply that members of Congress make better investment decisions as they spend more time in Congress.

\subsection{Power as Source of Information}

Karadas (2015) shows that common stock transactions by the powerful members of Congress contain much more value-relevant information than those by the non-powerful members. The improvement in the abnormal returns from the first term to the second term may be also caused by serving on a powerful committee. We use congressional committee assignments to identify the powerful members. The committee assignment data come from Stewart III and Woon (2011). We rely on the committee rankings by Stewart III and Woon (2011), who uses the approach developed in Groseclose and Stewart III (1998) to rank committees post-1994. We designate the top 10 influential committees in each chamber as powerful. These committees include Ways \& Means and Appropriations in the House, and Finance and Armed Services in the Senate. The full list for each chamber can be found in Stewart III and Woon (2011). Some members transition to powerful committees during a given congressional term. Therefore, the same member's trades can show up in both powerful and non-powerful samples depending on his or her committee assignments in the same congressional term.

We separately analyze the portfolio performance of the powerful and non-powerful mem- 
bers in their first and second terms. In the First Congress portfolio, there are 10 powerful members with 522 transactions, and 12 non-powerful members with 2,474 transactions. In the Second Congress portfolio, there are 13 powerful members with 3,128 transactions, and 6 non-powerful members with 2,344 transactions.

Table 6 shows the portfolio performance of the first-term members of Congress. There is no evidence of informed trading for the non-powerful members of Congress. However, there is poor portfolio performance indicated by significantly negative alphas for the powerful firstterm members at the 1-week holding period. We have a completely opposite picture when we look at the results in Table 7. For the second-term, the portfolios of powerful members earn statistically significant abnormal returns consistently at the 3 and 12-month holding periods.

The results in Tables 6 and 7 present a very interesting picture on the role of power in access to information. The non-powerful members' portfolios show lack of informed trading in both their first and second terms. However, the change in the information content of trades by the powerful members from the first term to the second term is drastic and warrants careful explanation. The results suggests that non-powerful members lack access to valuerelevant information, and thus their portfolios do not earn abnormal returns. On the other hand, the benefits from being on a powerful committee do not emerge until the second term. It is possible that first-term powerful members try to trade based on information, but they may lack either the experience to interpret information or may lack quality information to make informed decisions as they are new in their positions. By the time they are in the second term, it is likely that they have more experience and access to better information.

An additional possibility is that membership on an influential committee does not confer an informational advantage, but rather the power to influence policy in a manner that generates abnormal returns. The difference between the first and second term seems to be more consistent with the power channel rather than the information channel. There is also the possibility that the poor performance of the powerful members in the first term may be 
driven by the small sample (only 522 transactions). Politicians might just find it difficult to free up the time to trade given the demands of joining Congress and an influential committee. Overall, however, our results from the committee-based analysis reveals that membership on an influential committee is associated with abnormal returns for relatively new members of Congress.

\section{Conclusion}

In this paper we present evidence that members of Congress have no or very weak informational advantage in trading stocks prior to joining Congress. Further, we find that the informational advantage found in previous work does not appear immediately following election. Consistent with previous work, we find that there are significantly positive abnormal returns from serving in Congress but it takes two consecutive terms of service and powerful committee membership to obtain them. Overall, this paper sheds light on how serving in Congress leads to abnormal returns.

Our results, unfortunately, cannot distinguish between the information benefits of membership on an influential committee or the power associated with said committee. Our finding that membership on powerful committees does not lead to abnormal returns in the first year of service but does in the second is suggestive of the power mechanism, but further research needs to be done to distinguish between these two mechanisms. Thus while our results highlight the financial benefits of joining Congress and serving on an influential committee, we are not able to explain why members on powerful committees are able to earn abnormal returns. 


\section{References}

Anderson, S. C., Jackson, J. D., and Steagall, J. W. (1994). A note on odds in the cattle futures market. Journal of Economics and Finance, 18(3):357-365.

Bainbridge, S. M. (2011). Insider trading inside the beltway. The Journal of Corporation Law, 36:2.

Carhart, M. M. (1997). On persistence in mutual fund performance. Journal of Finance, $52(1): 57-82$.

Coker, D. C. and Crain, W. M. (1994). Legislative committees as loyalty-generating institutions. Public Choice, 81(3-4):195-221.

Eggers, A. C. and Hainmueller, J. (2014). Political capital: Corporate connections and stock investments in the US Congress, 2004-2008. Quarterly Journal of Political Science, $9(2): 169-202$.

Fama, E. F. and French, K. R. (1993). Common risk factors in the returns on stocks and bonds. Journal of Financial Economics, 33(1):3-56.

Fisman, R. (2001). Estimating the value of political connections. American Economic Review, 91(4):1095-1102.

Grier, K. B. and Munger, M. C. (1991). Committee assignments, constituent preferences, and campaign contributions. Economic Inquiry, 29(1):24-43.

Groseclose, T. and Stewart III, C. (1998). The value of committee seats in the house, 194791. American Journal of Political Science, 42(2):453-474.

Karadas, S. (2015). Informed trading at Capitol Hill: Evidence from members of Congress.

Knight, B. (2006). Are policy platforms capitalized into equity prices? Evidence from the Bush/Gore 2000 presidential election. Journal of Public Economics, 90(4):751-773. 
Manne, H. G. (1966). Insider trading and the stock market. Free Press, New York.

Milyo, J. (2014). Corporate influence and political corruption: Lessons from stock market reactions to political events. The Independent Review, 19(1):19-36.

Munger, M. C. (1988). Allocation of desirable committee assignments: Extended queues versus committee expansion. American Journal of Political Science, 32(2):317-344.

Odean, T. (1999). Do investors trade too much? American Economic Review, 89(5):12791298.

Pástor, L. and Stambaugh, R. F. (2003). Liquidity risk and expected stock returns. Journal of Political Economy, 111(3):642-685.

Shepsle, K. A. (1975). Congressional committee assignments. Public Choice, 22(1):55-78.

Stewart III, C. (2012). The value of committee assignments in Congress since 1994. MIT Political Science Department Working Paper 2012-7.

Stewart III, C. and Woon, J. (2011). Congressional committee assignments, 103rd to 114th congresses, 1993-2017.

Vardi, N. (2013). Did Obama and Congress use national security fears to gut the Stock Act? Forbes, April.

Ziobrowski, A. J., Boyd, J. W., Cheng, P., and Ziobrowski, B. J. (2011). Abnormal returns from the common stock investments of members of the US House of Representatives. Business and Politics, 13(1):1-22.

Ziobrowski, A. J., Cheng, P., Boyd, J. W., and Ziobrowski, B. J. (2004). Abnormal returns from the common stock investments of the US Senate. Journal of Financial and Quantitative Analysis, 39(4):661-676. 


\section{Table 1: Sample Selection Procedure}

In this table, we present the sample selection procedure for analyzing the portfolio returns of new members of Congress. We obtain the daily common stock transactions of new members of Congress from the Center for Responsive Politics for the 2004-2010 period. This dataset includes transactions during members' election (pre-congressional) and congressional service years.

\begin{tabular}{cccclll} 
Congress & Election & Begin & End & Pre-Congressional & Congressional & Included \\
\hline 108 & $11 / 5 / 2002$ & $1 / 3 / 2003$ & $1 / 3 / 2005$ & Unavailable & Available & No \\
109 & $11 / 4 / 2004$ & $1 / 3 / 2005$ & $1 / 3 / 2007$ & Available & Available & Yes \\
110 & $11 / 4 / 2006$ & $1 / 3 / 2007$ & $1 / 3 / 2009$ & Available & Available & Yes \\
111 & $11 / 4 / 2008$ & $1 / 3 / 2009$ & $1 / 3 / 2011$ & Available & Available & Yes \\
112 & $11 / 4 / 2010$ & $1 / 3 / 2011$ & $1 / 3 / 2013$ & Available & Unavailable & Yes \\
\hline
\end{tabular}




\section{Table 2: Abnormal Returns on the Pre-Congressional Portfolios, Full Sample}

In this table, we present the percentage average monthly risk-adjusted returns (alphas) and the raw returns on the portfolios constructed from the transactions that the new members of Congress made during their election year. The election years are 2004 for the $109^{\text {th }}$ Congress, 2006 for the $110^{\text {th }}$ Congress, 2008 for the $111^{\text {th }}$ Congress, and 2010 for the $112^{\text {th }}$ Congress. We obtain the transactions data from Center for Responsive Politics, the stock returns data from Center for Research in Security Prices (CRSP), and excess market returns, size, book-to-market, and liquidity factors from Wharton Research Data Services (WRDS). In constructing the portfolio returns for each member of Congress, each transaction is either weighted equally or by transaction size. In constructing the overall (i.e., average) portfolio returns, member-level portfolios are weighted equally. We follow these procedures in constructing an overall buy and an overall sell portfolio, and focus on the returns on the buy-minus-sell portfolio. We hold this buy-minus-sell portfolio for $1 / 4,1,2,3,6$, and 12 months periods. As a result, our sample period ranges from 2004M01 to 2011M12. We measure the risk-adjusted returns via Capital Asset Pricing Model (CAPM), Fama-French 3-Factor Model (FF), Carhart 4-Factor Model, and 5-Factor Model based on Newey-West adjusted standard errors using 3 lags, and report the associated t-statistics in parenthesis. We denote the 10,5 , and $1 \%$ significance levels with $*, * *, * * *$, respectively.

\begin{tabular}{lcccccc}
\hline Holding Period (Months): & $1 / 4$ & 1 & 2 & 3 & 6 & 12 \\
\hline & Panel A: Equal-Weighted Transactions & & \\
\hline Avg. Return & -1.199 & -1.224 & 0.143 & 0.707 & 0.142 & 0.761 \\
& $(-0.96)$ & $(-1.27)$ & $(0.15)$ & $(0.78)$ & $(0.25)$ & $(1.57)$ \\
CAPM Alpha & -1.103 & -1.225 & 0.163 & 0.717 & 0.173 & $0.813^{*}$ \\
& $(-1.10)$ & $(-1.40)$ & $(0.20)$ & $(0.75)$ & $(0.33)$ & $(1.88)$ \\
FF Alpha & -1.414 & -1.053 & -0.097 & 0.901 & 0.070 & $0.782^{*}$ \\
& $(-1.41)$ & $(-1.41)$ & $(-0.15)$ & $(0.99)$ & $(0.15)$ & $(1.95)$ \\
Carhart Alpha & -1.326 & -1.158 & -0.036 & 0.960 & 0.071 & $0.787^{* *}$ \\
& $(-1.38)$ & $(-1.54)$ & $(-0.06)$ & $(1.07)$ & $(0.15)$ & $(1.99)$ \\
5-Factor Alpha & -1.778 & -1.357 & -0.058 & 1.424 & 0.015 & $0.881^{* *}$ \\
& $(-1.55)$ & $(-1.47)$ & $(-0.08)$ & $(1.24)$ & $(0.03)$ & $(2.19)$ \\
\hline \multirow{5}{*}{ Avg. Return } & Panel B: Value-Weighted Transactions & & \\
CAPM Alpha & -1.122 & -1.101 & 0.290 & 0.795 & -0.032 & 0.616 \\
& $(-0.87)$ & $(-1.09)$ & $(0.31)$ & $(0.87)$ & $(-0.05)$ & $(1.26)$ \\
FF Alpha & -1.036 & -1.112 & 0.295 & 0.808 & 0.001 & 0.654 \\
& $(-0.90)$ & $(-1.17)$ & $(0.35)$ & $(0.83)$ & $(0.00)$ & $(1.50)$ \\
Carhart Alpha & -1.348 & -0.891 & 0.029 & 0.948 & -0.120 & 0.611 \\
& $(-1.18)$ & $(-1.10)$ & $(0.04)$ & $(1.04)$ & $(-0.23)$ & $(1.51)$ \\
5-Factor Alpha & -1.250 & -1.000 & 0.086 & 1.007 & -0.108 & 0.614 \\
& $(-1.13)$ & $(-1.21)$ & $(0.14)$ & $(1.12)$ & $(-0.21)$ & $(1.53)$ \\
& -1.785 & -1.174 & 0.070 & 1.560 & -0.130 & $0.756^{*}$ \\
& $(-1.36)$ & $(-1.20)$ & $(0.10)$ & $(1.37)$ & $(-0.23)$ & $(1.84)$ \\
\hline
\end{tabular}




\section{Table 3: Abnormal Returns on Pre-Congressional Portfolios, Consistent Traders}

In this table, we present the percentage average monthly risk-adjusted returns (alphas) and the raw returns on the portfolios constructed from the transactions that the freshmen members of Congress made during their election year. For a transaction to be included in this sample, trading member must have stock trades in two consecutive terms following his or her election. The election years are 2004 for the $109^{\text {th }}$ Congress and 2006 for the $110^{\text {th }}$ Congress. We obtain the transactions data from Center for Responsive Politics, the stock returns data from Center for Research in Security Prices (CRSP), and excess market returns, size, book-to-market, and liquidity factors from Wharton Research Data Services (WRDS). In constructing the portfolio returns for each member of Congress, each transaction is either weighted equally or by transaction size. In constructing the overall (i.e., average) portfolio returns, member-level portfolios are weighted equally. We follow these procedures in constructing an overall buy and an overall sell portfolio, and focus on the returns on the buy-minus-sell portfolio. We hold this buyminus-sell portfolio for 1/4, 1, 2, 3, 6, and 12 months periods. As a result, our sample period ranges from 2004M01 to 2007M12. We measure the risk-adjusted returns via Capital Asset Pricing Model (CAPM), Fama-French 3-Factor Model (FF), Carhart 4-Factor Model, and 5-Factor Model based on Newey-West adjusted standard errors using 3 lags, and report the associated t-statistics in parenthesis. We denote the 10,5 , and $1 \%$ significance levels with $*, * *, * * *$, respectively.

\begin{tabular}{lcccccc}
\hline Holding Period (Months): & $1 / 4$ & 1 & 2 & 3 & 6 & 12 \\
\hline & Panel A: Equal-Weighted & Transactions & & \\
\hline Avg. Return & 0.317 & -1.217 & -0.606 & 0.032 & -0.465 & -0.013 \\
& $(0.21)$ & $(-1.17)$ & $(-0.71)$ & $(0.04)$ & $(-0.64)$ & $(-0.02)$ \\
CAPM Alpha & 0.451 & $-1.429^{*}$ & -0.551 & 0.044 & -0.387 & 0.137 \\
& $(0.37)$ & $(-1.78)$ & $(-0.92)$ & $(0.08)$ & $(-0.67)$ & $(0.30)$ \\
FF Alpha & -0.974 & $-1.796^{* * *}$ & -0.629 & 0.131 & -0.509 & 0.173 \\
& $(-0.94)$ & $(-3.33)$ & $(-1.03)$ & $(0.17)$ & $(-0.78)$ & $(0.33)$ \\
Carhart Alpha & -1.145 & -1.111 & -0.105 & 0.475 & -0.229 & 0.050 \\
& $(-0.86)$ & $(-1.36)$ & $(-0.17)$ & $(0.68)$ & $(-0.37)$ & $(0.10)$ \\
5-Factor Alpha & -0.726 & -0.820 & 0.310 & 0.941 & 0.129 & 0.505 \\
& $(-0.52)$ & $(-0.82)$ & $(0.38)$ & $(1.19)$ & $(0.21)$ & $(0.95)$ \\
\hline \multirow{5}{*}{ Avg. Return } & Panel B: Value-Weighted Transactions & & \\
& 0.451 & -0.951 & -0.642 & 0.012 & -0.495 & -0.115 \\
CAPM Alpha & $(0.29)$ & $(-0.84)$ & $(-0.67)$ & $(0.01)$ & $(-0.67)$ & $(-0.20)$ \\
& 0.589 & -1.187 & -0.736 & -0.061 & -0.478 & -0.013 \\
FF Alpha & $(0.40)$ & $(-1.17)$ & $(-1.06)$ & $(-0.09)$ & $(-0.83)$ & $(-0.03)$ \\
& -1.149 & $-2.065^{* * *}$ & -1.011 & -0.207 & -0.690 & 0.031 \\
Carhart Alpha & $(-1.02)$ & $(-3.00)$ & $(-1.25)$ & $(-0.24)$ & $(-0.97)$ & $(0.05)$ \\
& -1.604 & $-1.224^{*}$ & -0.520 & 0.190 & -0.414 & -0.085 \\
5-Factor Alpha & $(-1.05)$ & $(-1.78)$ & $(-0.75)$ & $(0.26)$ & $(-0.63)$ & $(-0.14)$ \\
& -1.315 & -0.992 & 0.007 & 0.699 & -0.072 & 0.380 \\
& $(-0.80)$ & $(-1.04)$ & $(0.01)$ & $(0.85)$ & $(-0.11)$ & $(0.66)$ \\
\hline
\end{tabular}




\section{Table 4: Abnormal Returns on the First Congress Portfolios, Consistent Traders}

In this table, we present the percentage average monthly risk-adjusted returns (alphas) and the raw returns on the portfolios constructed from the transactions that the new members of Congress made during their first term in Congress. For a transaction to be included in this sample, trading member must have stock trades in the election year and in the two consecutive terms following his or her election. The first terms are 2005 and 2006 for those elected to the $109^{\text {th }}$ Congress and 2007 and 2008 for those elected to the $110^{\text {th }}$ Congress. We obtain the transactions data from Center for Responsive Politics, the stock returns data from Center for Research in Security Prices (CRSP), and excess market returns, size, book-to-market, and liquidity factors from Wharton Research Data Services (WRDS). In constructing the portfolio returns for each member of Congress, each transaction is either weighted equally or by transaction size. In constructing the overall (i.e., average) portfolio returns, member-level portfolios are weighted equally. We follow these procedures in constructing an overall buy and an overall sell portfolio, and focus on the returns on the buy-minus-sell portfolio. We hold this buy-minus-sell portfolio for $1 / 4$, $1,2,3,6$, and 12 months periods. As a result, our sample period ranges from 2005M01 to 2009M12. We measure the risk-adjusted returns via Capital Asset Pricing Model (CAPM), Fama-French 3-Factor Model (FF), Carhart 4-Factor Model, and 5-Factor Model based on Newey-West adjusted standard errors using 3 lags, and report the associated t-statistics in parenthesis. We denote the 10, 5, and $1 \%$ significance levels with $*, * *, * * *$, respectively.

\begin{tabular}{lcccccc}
\hline Holding Period (Months): & $1 / 4$ & 1 & 2 & 3 & 6 & 12 \\
\hline Avg. Return & Panel A: Equal-Weighted Transactions & & \\
& -1.860 & -0.702 & 0.042 & 0.777 & -0.667 & 0.038 \\
CAPM Alpha & $(-1.59)$ & $(-1.09)$ & $(0.05)$ & $(0.72)$ & $(-1.39)$ & $(0.09)$ \\
& -2.063 & -0.883 & -0.081 & 1.124 & -0.675 & 0.033 \\
FF Alpha & $(-1.39)$ & $(-1.48)$ & $(-0.13)$ & $(0.87)$ & $(-1.37)$ & $(0.10)$ \\
& -1.987 & -0.908 & -0.062 & 1.161 & -0.643 & 0.013 \\
Carhart Alpha & $(-1.35)$ & $(-1.63)$ & $(-0.10)$ & $(0.86)$ & $(-1.38)$ & $(0.04)$ \\
& -2.308 & $-1.065^{*}$ & 0.026 & 1.606 & -0.617 & 0.017 \\
5-Factor Alpha & $(-1.51)$ & $(-1.79)$ & $(0.04)$ & $(1.21)$ & $(-1.43)$ & $(0.05)$ \\
& -2.577 & -0.669 & -0.486 & 1.728 & $-0.764^{*}$ & -0.110 \\
& $(-1.57)$ & $(-1.17)$ & $(-0.77)$ & $(1.14)$ & $(-1.81)$ & $(-0.35)$ \\
\hline Avg. Return & Panel B: Value-Weighted Transactions & & \\
CAPM Alpha & $-2.170^{*}$ & -0.955 & -0.223 & 0.370 & -0.622 & -0.058 \\
& $(-1.72)$ & $(-1.34)$ & $(-0.24)$ & $(0.34)$ & $(-1.31)$ & $(-0.14)$ \\
FF Alpha & -2.384 & -1.121 & -0.289 & 0.754 & -0.621 & -0.064 \\
& $(-1.53)$ & $(-1.65)$ & $(-0.42)$ & $(0.59)$ & $(-1.26)$ & $(-0.20)$ \\
Carhart Alpha & -2.301 & $-1.131^{*}$ & -0.251 & 0.797 & -0.591 & -0.081 \\
& $(-1.52)$ & $(-1.76)$ & $(-0.37)$ & $(0.60)$ & $(-1.29)$ & $(-0.26)$ \\
5-Factor Alpha & -2.682 & $-1.220^{*}$ & -0.132 & 1.252 & -0.581 & -0.079 \\
& $(-1.67)$ & $(-1.81)$ & $(-0.20)$ & $(0.95)$ & $(-1.30)$ & $(-0.26)$ \\
& $-3.022^{*}$ & -0.755 & -0.619 & 1.376 & -0.626 & -0.155 \\
& $(-1.73)$ & $(-1.24)$ & $(-0.91)$ & $(0.92)$ & $(-1.38)$ & $(-0.50)$ \\
\hline
\end{tabular}




\section{Table 5: Abnormal Returns on the Second Congress Portfolios, Consistent}

Traders

In this table, we present the percentage average monthly risk-adjusted returns (alphas) and the raw returns on the portfolios constructed from the transactions that the new members of Congress made during their second term in Congress. For a transaction to be included in this sample, trading member must have stock trades in the election year and in the two consecutive terms following his or her election. The second terms are 2007 and 2008 for those elected to the $109^{\text {th }}$ Congress and 2009 and 2010 for those elected to the $110^{t h}$ Congress. We obtain the transactions data from Center for Responsive Politics, the stock returns data from Center for Research in Security Prices (CRSP), and excess market returns, size, book-to-market, and liquidity factors from Wharton Research Data Services (WRDS). In constructing the portfolio returns for each member of Congress, each transaction is either weighted equally or by transaction size. In constructing the overall (i.e., average) portfolio returns, member-level portfolios are weighted equally. We follow these procedures in constructing an overall buy and an overall sell portfolio, and focus on the returns on the buy-minus-sell portfolio. We hold this buy-minus-sell portfolio for $1 / 4$, 1, 2, 3, 6, and 12 months periods. As a result, our sample period ranges from 2007M01 to $2011 \mathrm{M} 12$. We measure the risk-adjusted returns via Capital Asset Pricing Model (CAPM), Fama-French 3-Factor Model (FF), Carhart 4-Factor Model, and 5-Factor Model based on Newey-West adjusted standard errors using 3 lags, and report the associated t-statistics in parenthesis. We denote the 10, 5, and $1 \%$ significance levels with $*, * *, * * *$, respectively.

\begin{tabular}{lcccccc}
\hline Holding Period (Months): & $1 / 4$ & 1 & 2 & 3 & 6 & 12 \\
\hline & Panel A: Equal-Weighted Transactions & & \\
\hline Avg. Return & -1.843 & -0.973 & -0.473 & 0.907 & -0.042 & $0.835^{*}$ \\
& $(-1.37)$ & $(-1.21)$ & $(-0.64)$ & $(1.31)$ & $(-0.07)$ & $(1.69)$ \\
CAPM Alpha & -1.852 & -0.981 & -0.485 & 0.875 & -0.061 & $0.837^{*}$ \\
& $(-1.10)$ & $(-1.26)$ & $(-0.58)$ & $(1.22)$ & $(-0.10)$ & $(1.85)$ \\
FF Alpha & -1.841 & -0.984 & -0.234 & $1.237^{* *}$ & -0.005 & $0.806^{* *}$ \\
& $(-1.08)$ & $(-1.26)$ & $(-0.30)$ & $(2.02)$ & $(-0.01)$ & $(2.08)$ \\
Carhart Alpha & -1.693 & -0.998 & -0.231 & $1.270^{* *}$ & 0.022 & $0.809^{* *}$ \\
& $(-1.04)$ & $(-1.24)$ & $(-0.29)$ & $(2.05)$ & $(0.04)$ & $(2.07)$ \\
5-Factor Alpha & -1.518 & -0.865 & -0.143 & $1.375^{* *}$ & 0.026 & $0.818^{* *}$ \\
& $(-0.91)$ & $(-1.01)$ & $(-0.17)$ & $(2.02)$ & $(0.05)$ & $(2.02)$ \\
\hline \multirow{5}{*}{ Avg. Return } & Panel B: Value-Weighted Transactions & & \\
& -1.404 & -0.840 & -0.718 & 0.628 & -0.230 & 0.702 \\
CAPM Alpha & $(-1.10)$ & $(-1.03)$ & $(-0.94)$ & $(0.88)$ & $(-0.40)$ & $(1.44)$ \\
& -1.405 & -0.845 & -0.728 & 0.596 & -0.253 & 0.703 \\
FF Alpha & $(-0.82)$ & $(-1.00)$ & $(-0.85)$ & $(0.84)$ & $(-0.42)$ & $(1.59)$ \\
& -1.294 & -0.812 & -0.467 & 0.971 & -0.083 & $0.722^{*}$ \\
Carhart Alpha & $(-0.77)$ & $(-0.97)$ & $(-0.57)$ & $(1.58)$ & $(-0.16)$ & $(1.86)$ \\
& -1.157 & -0.824 & -0.452 & 1.023 & -0.051 & $0.730^{*}$ \\
5-Factor Alpha & $(-0.72)$ & $(-0.96)$ & $(-0.55)$ & $(1.67)$ & $(-0.10)$ & $(1.84)$ \\
& -0.967 & -0.664 & -0.362 & $1.127^{*}$ & -0.041 & $0.744^{*}$ \\
& $(-0.59)$ & $(-0.74)$ & $(-0.41)$ & $(1.70)$ & $(-0.08)$ & $(1.77)$ \\
\hline
\end{tabular}


Table 6: Abnormal Returns on the First Congress: Powerful versus Non-Powerful

In this table, we report the percentage average monthly risk-adjusted returns (alphas) and the raw returns on the portfolios constructed from the transactions that the powerful and non-powerful members of Congress made during their first term in Congress. For a transaction to be included in this sample, trading member must have stock trades in the election year and in the two consecutive terms following his or her election. The first terms are 2005 and 2006 for those elected to the $109^{\text {th }}$ Congress and 2007 and 2008 for those elected to the $110^{t h}$ Congress. We obtain the transactions data from Center for Responsive Politics, the stock returns data from Center for Research in Security Prices (CRSP), and excess market returns, size, book-to-market, and liquidity factors from Wharton Research Data Services (WRDS). In constructing the portfolio returns for each member of Congress, each transaction is either weighted equally or by transaction size. In constructing the overall (i.e., average) portfolio returns, member-level portfolios are weighted equally. We follow these procedures in constructing an overall buy and an overall sell portfolio, and focus on the returns on the buy-minus-sell portfolio. We hold this buy-minus-sell portfolio for $1 / 4,1,2,3,6$, and 12 months periods. As a result, our sample period ranges from 2005M01 to 2009M12. We measure the risk-adjusted returns via Capital Asset Pricing Model (CAPM), Fama-French 3-Factor Model (FF), Carhart 4-Factor Model, and 5-Factor Model based on Newey-West adjusted standard errors using 3 lags, and report the associated t-statistics in parenthesis. We denote the 10,5 , and $1 \%$ significance levels with $*,{ }^{* *},{ }^{* *}$, respectively. We only show the results for the portfolios with equal-weighted transactions to save space. The results for the portfolios with the value-weighted transactions are very similar.

\begin{tabular}{|c|c|c|c|c|c|c|}
\hline Holding Period (Months): & $1 / 4$ & 1 & 2 & 3 & 6 & 12 \\
\hline \multicolumn{7}{|c|}{ Panel A: Powerful. Equal-Weighted Transactions } \\
\hline Avg. Return & $\begin{array}{c}-2.949^{* *} \\
(-2.25)\end{array}$ & $\begin{array}{l}-0.607 \\
(-0.66)\end{array}$ & $\begin{array}{l}-0.406 \\
(-0.53)\end{array}$ & $\begin{array}{l}0.370 \\
(0.54)\end{array}$ & $\begin{array}{l}0.009 \\
(0.02)\end{array}$ & $\begin{array}{l}0.316 \\
(0.62)\end{array}$ \\
\hline CAPM Alpha & $\begin{array}{c}-3.113^{* * *} \\
(-2.85)\end{array}$ & $\begin{array}{l}-0.924 \\
-1.22)\end{array}$ & $\begin{array}{l}-0.387 \\
(-0.48)\end{array}$ & $\begin{array}{l}0.403 \\
(0.57)\end{array}$ & $\begin{array}{l}0.025 \\
(0.05)\end{array}$ & $\begin{array}{l}0.319 \\
(0.70)\end{array}$ \\
\hline FF Alpha & $\begin{array}{c}-3.090 * * * \\
(-2.78)\end{array}$ & $\begin{array}{l}-1.042 \\
(-1.57)\end{array}$ & $\begin{array}{l}-0.377 \\
(-0.47)\end{array}$ & $\begin{array}{l}0.449 \\
(0.65)\end{array}$ & $\begin{array}{l}-0.011 \\
(-0.03)\end{array}$ & $\begin{array}{l}0.261 \\
(0.66)\end{array}$ \\
\hline Carhart Alpha & $\begin{array}{c}-2.972^{* *} \\
(-2.45)\end{array}$ & $\begin{array}{l}-1.261 \\
(-1.40)\end{array}$ & $\begin{array}{l}-0.234 \\
(-0.27)\end{array}$ & $\begin{array}{l}0.635 \\
(0.86)\end{array}$ & $\begin{array}{l}-0.031 \\
(-0.07)\end{array}$ & $\begin{array}{l}0.253 \\
(0.65)\end{array}$ \\
\hline 5-Factor Alpha & $\begin{array}{c}-3.073^{* *} \\
(-2.38)\end{array}$ & $\begin{array}{l}-0.923 \\
(-1.15)\end{array}$ & $\begin{array}{l}-0.608 \\
(-0.69)\end{array}$ & $\begin{array}{l}0.196 \\
(0.26)\end{array}$ & $\begin{array}{l}-0.101 \\
(-0.23)\end{array}$ & $\begin{array}{l}0.186 \\
(0.46)\end{array}$ \\
\hline \multicolumn{7}{|c|}{ Panel B: Non-powerful. Equal-Weighted Transactions } \\
\hline Avg. Return & $\begin{array}{l}-0.659 \\
(-0.36)\end{array}$ & $\begin{array}{l}-0.256 \\
(-0.29)\end{array}$ & $\begin{array}{l}0.487 \\
(0.47)\end{array}$ & $\begin{array}{l}0.538 \\
(0.48)\end{array}$ & $\begin{array}{l}-0.425 \\
(-0.65)\end{array}$ & $\begin{array}{l}-0.328 \\
(-0.57)\end{array}$ \\
\hline CAPM Alpha & $\begin{array}{l}-1.021 \\
(-0.56)\end{array}$ & $\begin{array}{l}-0.288 \\
(-0.34)\end{array}$ & $\begin{array}{l}0.407 \\
(0.55)\end{array}$ & $\begin{array}{l}0.922 \\
(0.77)\end{array}$ & $\begin{array}{l}-0.362 \\
(-0.67)\end{array}$ & $\begin{array}{l}-0.334 \\
(-0.68)\end{array}$ \\
\hline FF Alpha & $\begin{array}{l}-0.693 \\
(-0.42)\end{array}$ & $\begin{array}{l}-0.222 \\
(-0.28)\end{array}$ & $\begin{array}{l}0.464 \\
(0.70)\end{array}$ & $\begin{array}{l}0.953 \\
(0.76)\end{array}$ & $\begin{array}{l}-0.325 \\
(-0.61)\end{array}$ & $\begin{array}{l}-0.333 \\
(-0.69)\end{array}$ \\
\hline Carhart Alpha & $\begin{array}{l}-1.055 \\
(-0.55)\end{array}$ & $\begin{array}{l}-0.281 \\
(-0.32)\end{array}$ & $\begin{array}{l}0.495 \\
(0.74)\end{array}$ & $\begin{array}{l}1.315 \\
(1.01)\end{array}$ & $\begin{array}{l}-0.282 \\
(-0.52)\end{array}$ & $\begin{array}{l}-0.307 \\
(-0.61)\end{array}$ \\
\hline 5-Factor Alpha & $\begin{array}{l}-1.060 \\
(-0.49)\end{array}$ & $\begin{array}{l}0.101 \\
(0.10)\end{array}$ & $\begin{array}{l}0.053 \\
(0.07)\end{array}$ & $\begin{array}{l}1.559 \\
(1.04)\end{array}$ & $\begin{array}{l}-0.310 \\
(-0.51)\end{array}$ & $\begin{array}{l}-0.332 \\
(-0.58)\end{array}$ \\
\hline
\end{tabular}




\section{Table 7: Abnormal Returns on Second Congress: Powerful versus Non-Powerful}

In this table, we report the average monthly risk-adjusted returns (alphas) and the raw returns on the portfolios constructed from the transactions that the powerful and non-powerful members of Congress made during their second term in Congress. For a transaction to be included in this sample, trading member must have stock trades in the election year and in the two consecutive terms following his or her election. The second terms are 2007 and 2008 for those elected to the $109^{\text {th }}$ Congress and 2009 and 2010 for those elected to the $110^{t h}$ Congress. We obtain the transactions data from Center for Responsive Politics, the stock returns data from Center for Research in Security Prices (CRSP), and excess market returns, size, book-to-market, and liquidity factors from Wharton Research Data Services (WRDS). In constructing the portfolio returns for each member of Congress, each transaction is either weighted equally or by transaction size. In constructing the overall (i.e., average) portfolio returns, member-level portfolios are weighted equally. We follow these procedures in constructing an overall buy and an overall sell portfolio, and focus on the returns on the buy-minus-sell portfolio. We hold this buy-minus-sell portfolio for $1 / 4,1,2,3,6$, and 12 months periods. As a result, our sample period ranges from 2007M01 to 2011M12. We measure the risk-adjusted returns via Capital Asset Pricing Model (CAPM), Fama-French 3-Factor Model (FF), Carhart 4-Factor Model, and 5-Factor Model based on Newey-West adjusted standard errors using 3 lags, and report the associated t-statistics in parenthesis. We denote the 10,5 , and $1 \%$ significance levels with ${ }^{*},{ }^{* *},{ }^{* *}$, respectively. We only show the results for the portfolios with equal-weighted transactions to save space. The results for the portfolios with the value-weighted transactions are very similar.

\begin{tabular}{lcccccc}
\hline Holding Period (Months): & $1 / 4$ & 1 & 2 & 3 & 6 & 12 \\
\hline & Panel A: Powerful. Equal-Weighted & Transactions & \\
\hline Avg. Return & -1.165 & -1.318 & -0.276 & $1.593^{*}$ & 0.254 & $1.713^{* *}$ \\
& $(-0.85)$ & $(-1.23)$ & $(-0.31)$ & $(1.92)$ & $(0.34)$ & $(2.56)$ \\
CAPM Alpha & -1.135 & -1.318 & -0.285 & $1.525^{* *}$ & 0.249 & $1.717^{* * *}$ \\
& $(-0.68)$ & $(-1.24)$ & $(-0.35)$ & $(2.33)$ & $(0.39)$ & $(2.92)$ \\
FF Alpha & -1.193 & -1.517 & -0.261 & $1.962^{* * *}$ & 0.313 & $1.657^{* * *}$ \\
& $(-0.72)$ & $(-1.29)$ & $(-0.30)$ & $(3.41)$ & $(0.61)$ & $(3.01)$ \\
Carhart Alpha & -1.109 & -1.547 & -0.290 & $1.959^{* * *}$ & 0.302 & $1.639^{* * *}$ \\
& $(-0.72)$ & $(-1.29)$ & $(-0.34)$ & $(3.39)$ & $(0.59)$ & $(3.01)$ \\
5-Factor Alpha & -1.097 & -1.444 & -0.220 & $2.033^{* * *}$ & 0.322 & $1.679^{* * *}$ \\
& $(-0.70)$ & $(-1.13)$ & $(-0.24)$ & $(3.18)$ & $(0.63)$ & $(3.04)$ \\
\hline \multirow{5}{*}{ Avg. Return } & -1.200 & -0.900 & -1.525 & -1.528 & $-1.830^{*}$ & -1.371 \\
& $(-0.76)$ & $(-0.76)$ & $(-1.21)$ & $(-1.37)$ & $(-1.83)$ & $(-1.66)$ \\
CAPM Alpha & -1.366 & -0.890 & -1.564 & -1.472 & -1.827 & -1.371 \\
& $(-0.82)$ & $(-0.70)$ & $(-0.88)$ & $(-1.34)$ & $(-1.63)$ & $(-1.50)$ \\
FF Alpha & -1.176 & -0.616 & -0.857 & -1.139 & -1.490 & -1.226 \\
& $(-0.61)$ & $(-0.50)$ & $(-0.52)$ & $(-1.01)$ & $(-1.33)$ & $(-1.45)$ \\
Carhart Alpha & -1.303 & -0.684 & -0.662 & -0.844 & -1.222 & -1.118 \\
& $(-0.65)$ & $(-0.53)$ & $(-0.41)$ & $(-0.75)$ & $(-1.11)$ & $(-1.32)$ \\
5-Factor Alpha & -1.274 & -0.961 & -1.004 & -0.924 & -1.183 & -1.053 \\
& $(-0.68)$ & $(-0.77)$ & $(-0.61)$ & $(-0.88)$ & $(-1.22)$ & $(-1.43)$ \\
\hline
\end{tabular}

